\title{
CULTURE OF THE PEOPLES OF THE BALKAN PENINSULA: HISTORY AND MODERN INFLUENCE OF TURKEY
}

\author{
(C) Yulia A. Petrova, Valeriya V. Bukreyeva \\ Rostov State University of Economics, Rostov-on-Don, Russian Federation \\ science-almanac@mail.ru
}

\begin{abstract}
The article examines the cultural penetration of the Ottoman Empire into the territory of the Balkan Peninsula. The once developing peoples of the Balkans, overcoming their own crises, are becoming an indispensable goal of a rapidly emerging empire. The proximity to Europe and close interaction with it became a decisive factor for its conquest, as well as the inability of the allied countries to resist the Ottomans. The gradual seizure led to the complete elimination of most of the existing in the $12^{\text {th }}$ century independent states. For the most part, the dialogue of cultures took place as a forced assimilation. The result was the complete displacement of a foreign culture outside its own territory. Despite this, some of the cultural aspects have firmly entered the life of ordinary people and have become entrenched in it as part of their own culture. This article is dedicated to identifying these entrenched traditions as well as Turkey's contemporary influence in the Balkans.

Key words: Balkans, Turkey, culture, language, traditions.

\section{[Ю.А. Петрова, В.В. Букреева Культура народов Балканского полуострова: история и современ- ное влияние Турции]}

Исследуется культурное проникновение Османской империи на территорию Балканского полуострова. Некогда развивающиеся народы Балкан, преодолевающие собственные кризисы, становятся необходимой целью стремительно формирующейся империи. Близкое расположение к Европе и тесное взаимодействие с ней стали решающим фактором для ее завоевания, а также неспособность союзных стран противостоять османам. Постепенный захват привел к полной ликвидации большинства существующих в XII в. независимых государств. Диалог культур происходил в большей своей части как насильственная ассимиляция. Итогом послужило полное вытеснение инородной культуры за пределы собственной территории. Но, несмотря на это, часть культурных аспектов прочно вошла в жизнедеятельность обычных людей и закрепилась в ней как часть собственной культуры. Данная статья посвящена выявлению этих укрепившихся традиций, а также современному влиянию Турции на Балканы.

Ключевые слова: Балканы, Турция, культура, язык, традиции.
\end{abstract}

Yulia A. Petrova - Ph.D. in Philosophy, Associate Professor, Rostov State University of Economics, Rostov-onDon, Russian Federation.

Valeriya V. Bukreyeva - Student, Rostov State University of Economics, Rostov-on-Don, Russian Federation.

Петрова Юлия Андреевна - кандидат философьских наук, доцент, Ростовский государственный экономический университет, г. Ростов-на-Дону, Российская Федерация.

Букреева Валерия Владимировна - студентка, Ростовский государственный экономический универcuтет, г. Ростов-на-Дону, Российская Федерация.

At the beginning of the $11^{\text {th }}$ century, a small Turkic tribe began to develop rapidly, occupying at that time a small territory near the city of Bursa. In just a hundred years, from a feeble people who had barely escaped from the Mongol horde, the ancestors of the Ottomans managed to partially capture the weakened Byzantium and create the Konya Sultanate on the occupied territory. The need to strengthen the territories prompts, who came to power, Osman I to continue the conquest of neighboring territories. So, by the middle of the $14^{\text {th }}$ century, the Ottoman Turks, entrenched in Asia Minor, began to enslave the Balkan Peninsula.

The Balkan Peninsula is home to countries such as Bulgaria, Albania, Bosnia and Herzegovina, Greece, Montenegro and Macedonia, Serbia, etc. In addition to the six main South 
Slavic peoples (Croats, Serbs, Slovenes, Macedonians, Montenegrins and Bosnians), the Balkans are occupied by the Hungarians (the autonomous region of Vojvodina within Serbia), Albanians (Serbia, Kosovo), Romanians, Gypsies, Turks, Italians, etc. In the 14 century, the Balkan Peninsula also consisted of heterogeneous principalities and kingdoms, interacting with each other and complementing each other. Most of them were overcome by feuds and internecine wars, on the one hand, and other external enemies, on the other. The borders of the European coast of the Balkans were relatively close to the warlike Turkish feudal lords.

In 1352, the Turks defeated the combined forces of the Serbs, Bulgarians and Byzantines and took the Tsimpe fortress, their first stronghold in the Balkans. In 1360, they took Adrianople, which became the capital of the Ottoman Sultanate. In 1371, the Turks defeated the Macedonian army and began to raid the territory of Bulgaria, Serbia and Bosnia. The decisive battle took place on June 15, 1389 on the Kosovo field near the city of Pristina. The battle ended with Serbia becoming a vassal of the Turks in 1389. In 1459 it was incorporated into the Ottoman Empire. By 1396, the Turks crushed the Bulgarian kingdom and completely captured Macedonia and Thessaly [6, p. 41]. In 1453, the battle for Constantinople took place, as a result of which the Byzantine Empire ceased to exist.

Thus, for 400 years, the Balkans became part of the Ottoman Empire. Needless to say, the tyranny of the Turkish Khanate extended to all spheres of life of the subordinate peoples. This was especially true of the economic and political field, but the cultural factor also changed and adjusted to the habits and traditions of the Turks.

The etymology of the word "Balkans" can tell about this. Researchers attribute it to Turkic roots. From Turkish. balkan - "a chain of steep wooded mountains", but balgam, balgan "swamp", "swamp", "bog", "puddle", "mud" [3, p. 653].

A serious slowdown in the further progressive development of the Balkan peoples occurred due to the rooting of feudalism, which led to a gradual decrease in the rate of economic growth. The captured states were also obliged to pay tribute and give children to military service, peasants were considered powerless, so they were often taken into slavery. All this led to a decrease in the productive forces. Also, the peoples of the Balkans were burdened with a number of rules that were considered offensive at that time. For example, it was forbidden to ride a horse or carry a weapon. These conditions inevitably led to constant uprisings. They, in turn, were brutally suppressed, after which the rebellious cities were ravaged and burned.

Only those feudal lords who converted to Islam could save their economy. So they became a full part of the ruling class. Accordingly, ordinary slaves and peasants also had business. The adoption of Islam could bring them down to become not only free, but also political figures, court dignitaries.

The Islamization of the Balkan Peninsula is characterized by a relatively peaceful spread across the territory. Natives of the Byzantine and Roman empires did not abandon their principles and beliefs. Christianity remained the main religion of the Balkans, but now it was professed in secret. The need to accept Islam was also due to the gradual, confident policy of the Turkish khans. The Orthodox and Catholic churches that existed at that time were transferred to the Patriarchate of Constantinople, subordinate to the Turkish authorities.

Another part of the process of assimilation by Turkey of the Balkan Peninsula was the forcible withdrawal of boys into military service, where they were required to convert to Islam. Further training continued in all the canons of Islam.

Despite the attempts of the Turkish sultans to convert to their religion, the Balkan peoples remained true to their views, way of life and traditions. Despite this, the echoes of the past still shake the Balkans to this day.

Currently, such a term as "political Islam" has become widespread. Researchers from different countries interpret this term differently. This concept is used as an attempt to convey 
the meaning of a specific phenomenon in the religious and socio-political spheres. The renowned political analyst Graham Fuller equates "political Islam" and "Islamism", while under the Islamists implying those who believe that Islam should regulate socio-political processes and determine the course of the policy that the Islamic world should pursue [11, p. 227].

Now the Balkans are being conquered from two sides. Turkey, pursuing a regional policy, on the other hand, the dawn of the media leads to an active increase in followers through the promotion of its ideology. For example, the Peace TV channel is considered one of the main distributors of radical Islamic movements. Irfan al-Alawi, an employee of the Gatestone Institute for International Policy, warns in pure English: under the guise of so-called "moderate Islamism" - a false guise of extremism and radicalism - considerable forces of Wahhabis and deobandists flock to the Balkans, primarily in Kosovo, from all over the world and other Islamist terrorists [7].

If earlier radical movements and organizations in the Balkans acted in most cases secretly, today the activity of Islamists in the region is already visible to the naked eye. today the authorities of Western Europe are increasingly denying entry into the country, or even citizenship [4].

The massacre in Srebrenica in 1995 can be considered the influence of "political Islam". Now this case is considered one of the most massive killings in modern Europe. This event shows the beginning of the full-scale activity of a Muslim association in the Balkans, while Islam is losing its significance as a religion and becoming a political instrument for the implementation of the ideology of extremely radical movements. The main goal of these people is to gain control over certain regions of Europe.

Speaking of changing culture, one cannot but touch upon the change in the appearance of cities, architecture and art in general.

Until the end of the $18^{\text {th }}$ century, Europeans were not particularly eager to calm down anything about the countries of the Balkan Peninsula. It was believed that under the influence of the Ottoman Empire, developed and previously prosperous countries turned into the most backward, and some even became barbaric. This was associated with the fact that the Ottoman Empire as a whole did not produce anything and did not strive for any development, as well as the immorality of the Turkish government. With the liberation of the Balkans from the oppression of the Ottoman yoke, a lot of travelers rushed here, leaving various notes and notes about what they saw. It was difficult for Europeans to understand all the diversity of the culture of the Balkan peoples. Mingling with each other, and then with the culture of Turkey, the cities for them were just a multitude of dirty huts in which poor people dragged their miserable existence. The senseless jumble of buildings that differed from each other in the manner of implementation of architectural structures confirmed the opinion of Europeans about the degradation of the entire culture of the peninsula. But behind these chaotic, according to travelers, buildings hid an exceptional culture of the $19^{\text {th }}-20^{\text {th }}$ centuries Balkan. The cities were warring parties. On the one hand, it was an innovative Europe, and on the other, a static Turkey. It was a battle between East and West, between technology and backwardness.

The Ottoman Turks from the first days of fortification on the Balkan Peninsula considered it their duty to consolidate their architectural structure. The main goal was to perpetuate their own victories. Stone monuments of that era - public baths, mosques (Tombul Mosque in Shumen or Imaret Mosque in Plovdiv).

The form and style of the "Seljuk" monumental architecture in essence owed their education to the Armenian architecture and its creators. In addition, a number of forms of "Seljuk" architecture were direct reproduction of the forms of Armenian buildings [8]. Accordingly, this style was partially present in the architecture of the Balkan cities.

Under the influence of Ottoman architecture, the appearance of ordinary buildings also changed. Such innovations as the attic appear. 
Gradually, in countries such as Serbia and Bulgaria, trade and handicrafts begin, which is why the treasury was replenished. For the XVII century. the creation of clock towers is characteristic, as a symbol of the revival of self-awareness. The well-to-do class begins to stand out, respectively, the first mansions begin to appear. Examples of such buildings can be found in Bansko, Koprivshtitsa and Arbanassi.

The early period of development of the architecture of the Ottoman Empire is characterized by the search for new ideas and ways of their implementation. In this connection, styles that are unlike each other appear. Constant competition for originality of ideas led to the creation of houses, each of which had some distinctive feature.

Another feature of Turkish architecture was the transformation of backyards into colorful gardens. Entire neighborhoods with such houses have survived today.

In the Ottoman Empire, great importance was attached to drinking water. This was due to Islamic tenets. It was believed that if a person needs drinking water, it is necessary to drink him, only in this way can one later receive retribution from Allah. Therefore, any Turkish city of that time was characterized by the construction of a huge number of fountains. Absolutely everyone was involved in their construction: both ordinary people and sultans. Religion played an integral part of life in all spheres of activity.

After the liberation of the countries of Balkania from the oppression of the Ottoman Empire, all the creations of architecture were destroyed at a terrifying rate. Bulgaria, Serbia and other countries, after almost 5 centuries of regression, strove to become one of the developed countries of Europe as soon as possible. Proceeding from the fact that Europe is the complete opposite of Turkey, the cultural development of the Balkan people turned sharply in the opposite direction. In new, developing countries, there was no place for mosques and minarets. They, along with other architecture of the Turkish era, were considered a symbol of backwardness.

M. Todorova, a specialist in the history of the Balkan Peninsula in modern times, writes: "Balkan societies demonstrate several common features that are the direct result of the influence of the Ottoman Turks on them." Among these signs M. Todorova names authoritarian state control, the absence of aristocracy, a small and relatively weak philistine. All this explains why the ideas of egalitarianism are considered a characteristic feature of the region [10].

Probably, to a greater extent, one can speak of the influence of the Ottoman Empire in the linguistic aspect. A huge amount of borrowings still fills the language of the Balkan peoples. The fact that the Turkic component occupies a rather significant place in the culture of the former Yugoslav peoples is evidenced by the presence in the Serbo-Croatian language, as well as in folk poetry, songs, legends, proverbs and sayings of the South Slavic peoples of a large number of words of Turkic origin. The wide penetration and consolidation of Turkisms in the territories of the Balkan Slavs was also facilitated by the fact that Constantinople became a place where a large number of Muslims of Serbo-Croatian linguistic origin rushed to study [1, pp. 106-114].

Speaking about culture, one cannot but touch upon the topic of folklore. The culture of the Balkans is the interpenetration of the cultures of all countries. This can be best seen in the poems, songs and rhythms of these peoples. The traditional folklore of the Balkans is a mixture of the folklore of Greeks, Turks, Bulgarians, Romanians, Serbs and many others. Researchers have tried countless times to separate some tunes from others, but have come to disappointing conclusions. Experts are not able to unambiguously identify the main ethnic tradition. So, for example, in the folklore of the Romanians, absolutely all neighboring peoples are reflected. In the same way, you can find countless proverbs from each of the remaining peoples about the Romanians. For example, many traditional melodies that are national treasures of the Macedonians, Bulgarians or Albanians are of Turkish or Greek origin. In ad- 
dition, it should be said that with the widespread spread of Islam, legends containing Christian subjects and motives begin to mix with Muslim ones. Monoethnic soil made it impossible to operate with individual styles of storytelling.

The Turkish language has firmly entered the everyday life of the Balkan peoples. In some respects, so much so that one of the largest groups of borrowings is Turkish. There are especially many of them in the national Bulgarian language.

Turkish borrowings can be divided into three groups. Speaking of the Turkisms, one must start from the time when the Bulgarian Slavs or Slavs in general came into contact with the Turkish tribes in Asia or southern Russia and borrowed some words from Turkish. These words are different from the subsequent borrowings (Ottoman), because they are taken from Turkish tribes, which are quite different from the Ottoman Turks. Then a second layer of Turkish words appears, which come along with the Bulgarians of Khan Asparukh, that is, the tribe that forms the Bulgarian state. And finally, the third layer of words, which is the largest, comes in the period of the $14^{\text {th }}$ century, when the Turks (Ottoman) took possession of the Balkan Peninsula [2].

An example of a huge number of borrowings can be seen on the example of the language of Bulgaria.

Most of the words of Turkish origin are the names of handicrafts: zanayat - "craft", zanayatchiya - "artisan", jamdzhiya - "glazier", zarzavatchia - "greengrocer".

The influence of the Turkish language is also noticeable in the field of trade: pazar "market", dukyan - "shop, store", kervan - "caravan", sergia - "stall in the bazaar".

Turkish words are widely included in the judicial and administrative life of Bulgaria: qadiya - "judge", divan - "supreme state council", vilayet - "region", zaptiye - "gendarme". In military affairs there is also a certain group of Turkisms: asker - "army", barut - "gunpowder", kurshum - "bullet, lead", kama - "dagger", bayrak - "banner" and others [2].

In addition, a fairly large group of words are borrowings related to nature.

For example, the designation of icicles was rather unusually rooted among the Bulgarians: visulki, izsushiled, koleda, food, stockings (withers of birds), cones (cones), etc.

There are also enough Turkisms left in the modern language. They are found in all areas - in the names of foods, food, clothing, etc.

Bulgaria, like the rest of the peoples of the Balkan Peninsula, was under the yoke of the Ottoman Empire for almost 500 years. The tyranny and domination of the Turks forced them to partially or completely adopt their foundations, dialects, dialects, etc. But, despite all this, the irreconcilable Balkan peoples managed to largely preserve the Slavic basis of their languages in their original form.

Despite the terror and violence on the part of the Turks, all of the above aspects of culture continued to develop to one degree or another. Unfortunately, the same cannot be said for the literature of the Balkans. Only in the $16^{\text {th }}-17^{\text {th }}$ centuries. there is a flourishing of fiction. Oral folk art and monasteries contributed to the preservation of folk culture. It was here that ancient manuscripts were kept and gradually copied. Until the $16^{\text {th }}$ century. there was practically no fiction in the Balkans. The chronicles were the only exception. The chronicles contain original works telling about the Ottoman Empire from the side of military conflicts, bloodshed, violence and cruelty.

The establishment of the Turks in the Balkans is the reason for the fact that the monk Isaiah made a postscript to the Slavic translation of the works of Dionysius the Areopagite, which tells about the troubles of the Christian world in Eastern Macedonia after the Battle of Chernomen (1371). The records also reflect the expulsion of residents as a form of encroachment on compact Christian communities [5, p. 198].

The same is told in the annals and about the foreign policy of the Ottoman Empire. From them one can understand the attitude of the chroniclers and the entire people of the 
Balkans to the policy of the Turks. The consequences of wars, terrible famines, murders are described. The peoples of the Balkans perceived all these actions on the part of the ruling empire as "something marginal in relation to the entire Bulgarian nation as a whole, describing them with their inherent objectivity" [5, p. 198].

A characteristic feature of all Balkan peoples is a sense of duality, a lack of stable reference points. Long Ottoman rule brought provincialism and the loss of dynamism in development $[9$, p. 125-135].

As a result, the states of the Balkan Peninsula, almost a century after the collapse of the Ottoman Empire, continue to integrate into the modern world, geopolitical relations.

Despite the sharply negative attitude of the Balkans towards Turkey, the latter is making constant attempts to renew active political, economic and cultural ties with the regions. Turkey's active foreign policy is associated with the flourishing introduction of radical Islamic movements into the modern world order. In this new security environment, Turkey's political and strategic importance has increased due to several factors. The disappearance of the Soviet threat means that NATO's attention has now shifted to the south. Conflicts and potential hotbeds of concern today and for the foreseeable future include the Balkans, Russia, the South Caucasus and the Caspian Basin, Iran, Iraq, the Persian Gulf in general, Syria, Israel and North Africa. Turkey occupies a unique position next to all these countries and regions [12].

The Balkans, being an incredibly important element in geopolitical relations, need cooperation with developed states to ensure their own security. Partly located on the Balkan Peninsula, Turkey has a genuine interest in the fate of the region. Turkey has contributed to NATO and other international efforts to resolve the conflicts in Bosnia and Kosovo. Turkish military, police and observers have long continued to serve in various parts of the former $\mathrm{Yu}$ goslavia to ensure the safety and well-being of the civilian population [13].

And the latest news: "Turkey talks more about "new pragmatism" in the Balkans, and not about Islamic identity, and even presents the construction and restoration of mosques as the development of a network of cultural monuments to attract tourists and thus replenish the budgets of the Balkan countries. However, the EU is skeptical about such argumentation, and Europeans rather fear that Turkey is promoting political Islam to Europe through the Balkans".

At the same time, Turkey is actively establishing relations not only with Bosnia and Herzegovina, but also with Serbia, which prefers to close the page of historical confrontation for the sake of economic ties. By 2020, the trade turnover with Serbia alone is planned to reach $\$ 5$ billion" - according to the Inosmi.ru project (llya Plekhanov, creator and chief editor of Almanac "Art of War"). Thus, it can be considered that, despite the difficult relations between Eastern Turkey and the calling themselves Western Balkans in the past, today there is a gradual convergence of two states, similar in cultural and historical factors.

\section{Лumepamypa}

1. Абдирахман Г.Б. Тюрки и Южные Славяне: Некоторые аспекты межкультурного взаимодействия. Астана, 2016. С. 106-114.

2. Кандова Я. Заимствования в болгарском языке // Новая Литература. февраль, 2017 [Электронный ресурc], URL: http://newlit.ru/sale/2017_02.html (дата обращения:10.08.2020).

3. Мурзаев Э.М. Словарь народных географических терминов. Москва: Мысль, 1984. 653 c. 
4. Плещунов Ф. Исламисты наращивают своё присутствие на Балканах. Институт Ближнего Востока, 2012. [Электронный ресуpc], URL: http://www.iimes.ru/?p=15671 (дата обращения:17.08.2020).

5. Седакова И.А., Цивьян Т.В. В поисках ориентального на Балканах. Античность. Средневековье. Новое время. Балканские чтения 7. Тезисы и материалы. М.: Ин-т славяноведения РАН, 2003. 198 с.

6. Соколов Б.В. Сто великих войн. М.: Вече, 2001. 41 с.

7. Ананьев А.Г. Исламский фрактор на Балканах: современные тенденции и векторы развития // Исламоведение. 2013. № 4. [Электронный ресурc], URL: https://cyberleninka.ru/article/n/islamskiy-faktor-na-balkanah-sovremennye-tendentsii-ivektory-razvitiya/viewer (дата обращения: 05.08.20).

8. Якобсон А.Л. Сельджукские отклики на темы армянской средневековой архитектуры // Историко-фрилологический журнал.1983. № 4. С. 126-130. [Электронный ресурc], URL: http://hpj.asj-oa.am/3852/1/1983-4\%28126\%29.pdf (дата обращения: 05.08.20).

9. Бъчваров М., Бъчварова Б. Цивилизационните разнопосочия - недъг и харизма на Хомо Балканикус // Социална и културна география. София - Велико Търново: Унив. изд. Св.св. Кирил и Методий, 2004. С. 125-135.

10. Todorova M. Bałkany wyobraŜone. Wołowiec: Wyd. Czarne, 2008.

11. Graham E. Fuller. The future of political islam (New York: Palgrave Macmillan, 2003). XIX. -227 c.

12. Ministry of Foreign Affairs of the Republic of Turkey [Electronic resource] URL: http://www.mfa.gov.tr/nato.en.mfa (дата обращения: 20.08.20).

13. Nisanci S. Turkey's role in NATO in the Post-Cold War Security Environment // NATO research paper, Academic Research Branch. NATO Defense College, Rome, 2005. — № 16.

14. Petrova Y.A. Language consciousness as the peculiarity of cultural differences // Научный альманах стран Причерноморья. 2016. № 2 (6). С. 46-48.

15. Zhbannikova M., Milenkaya K. Beginning of medicine history study in Turkey: education and publications // Научный альманах стран Причерноморья. 2017. № 1

\section{References}

1. Abdirakhman G.B. Tyurki i Yuzhnyye Slavyane: Nekotoryye aspekty mezhkulturnogo vzaimodeystviya [Turks and Southern Slavs: Some Aspects of Intercultural Interaction]. Astana, 2016. pp. 106-114.

2. Kandova Ya. Zaimstvovaniya $v$ bolgarskom yazyke [Borrowings in the Bulgarian language]. Novaya Literatura. 02, 2017, Available at: http://newlit.ru/sale/2017_02.html, free (accessed 10.08.2020) (In Russian).

3. Murzayev E.M. Slovar narodnykh geograficheskikh terminov [Dictionary of folk geographic terms]. Moskva: Mysl, 1984. 653 p. (In Russian).

4. Pleshchunov F. Islamisty narashchivayut svoyo prisutstviye na Balkanakh [Islamists are increasing their presence in the Balkans]. Institut Blizhnego Vostoka, 2012, Available at: http://www.iimes.ru/?p=15671, free (accessed 17.08.2020) (In Russian).

5. Sedakova I.A., Tsivyan T.V. V poiskakh oriyentalnogo na Balkanakh. Antichnost. Srednevekovye. Novoye vremya. Balkanskiye chteniya 7. Tezisy i materialy [In search of the oriental in the Balkans. Antiquity. Middle Ages. New time. Balkan readings 7. Abstracts and materials]. Moscow: Institute slavyanovedeniya RAN, 2003. 198 p. (In Russian). 
6. Sokolov B.V. Sto velikikh voyn [One hundred great wars]. Moscow: Veche, 2001. 41 p. (In Russian).

7. Ananyev A.G. Islamskiy faktor na Balkanakh: sovremennyye tendentsii i vektory razvitiya [Islamic factor in the Balkans: current trends and vectors of development]. Islamovedeniye. 2013. No. 4, Available at: https://cyberleninka.ru/article/n/islamskiy-faktor-nabalkanah-sovremennye-tendentsii-i-vektory-razvitiya/viewer, free (accessed 05.08.20) (In Russian).

8. Yakobson A.L. Seldzhukskiye otkliki na temy armyanskoy srednevekovoy arkhitektury [Seljuk responses to the themes of Armenian medieval architecture]. Istorikofilologicheskiy zhurnal.1983. No. 4. pp. 126-130. Available at: http://hpj.asjoa.am/3852/1/1983-4(126).pdf, free (accessed 05.08.20) (In Russian).

9. Bŭchvarov M., Bŭchvarova B. Tsivilizatsionnye raznoposochen - nedug i kharizma na Khomo Balkanikus [Civilizations are diverse - illness and charisma on Homo Balkanicus]. Sotsialna i kulturna geografiya. Sofiya - Veliko Tŭrnovo: Univ. izd. Sv.sv. Kiril i Metodiĭ, 2004. pp. 125-135. (In Bulgarian).

10. Todorova M. Bałkany wyobraŜone. Wołowiec: Wyd. Czarne, 2008 (In Polish).

11. Graham E. Fuller. The future of political Islam. New York: Palgrave Macmillan, 2003. XIX. 227 p.

12. Ministry of Foreign Affairs of the Republic of Turkey, Available at: http://www.mfa.gov.tr/nato.en.mfa, free (accessed 20.08.20).

13. Nisanci S. Turkey's role in NATO in the Post-Cold War Security Environment. NATO research paper, Academic Research Branch. NATO Defense College, Rome, 2005. No.16.

14. Petrova Y.A. Language consciousness as the peculiarity of cultural differences. Science Almanac of Black Sea Region Countries. 2016. No.2 (6). pp. 46-48.

15. Zhbannikova M., Milenkaya K. Beginning of medicine history study in Turkey: education and publications. Science Almanac of Black Sea Region Countries. 2017. No.1. pp. 1217. 